\title{
Therapeutic usage of omeprazole and corticoid in a dog with hydrocephalus unresponsive to conventional therapy
}

\section{Uso terapêutico da associação do omeprazol com corticóide em um cão com hidrocefalia não-responsiva ao tratamento convencional}

\author{
Alexandre Mendes Amude ${ }^{1 *}$; Rosana Zanatta ${ }^{2}$; Raquel de Souza Lemos ${ }^{3}$; Lidiane \\ Pelegrini ${ }^{4}$; Katiuzi Quadros Alba ${ }^{5}$; Fernanda Viccini ${ }^{5}$; Amauri Alcindo Alfieri ${ }^{6}$
}

\begin{abstract}
Medical therapy for hydrocephalus includes the administration of medications to limit the production of the cerebrospinal fluid (CSF) resulting in reduced intracranial pressure (ICP). This report describes the clinical findings in one dog with congenital hydrocephalus that was unresponsive to conventional medical treatment with steroids, but demonstrated good response to omeprazole when this drug was added to the steroid. Omeprazole might decrease the CSF production by about $26 \%$ according to experimental studies with healthy dogs, but the usage of the omeprazole in clinical trials with affected dogs such as hydrocephalic animals is lacking. The results of this report might suggest that omeprazole can be used added to steroids to ameliorate the neurological status in dogs with increased ICP by hydrocephalus.
\end{abstract}

Key words: Omeprazole, cerebrospinal fluid, hydrocephalus

\section{Resumo}

O tratamento médico para a hidrocefalia inclui a administração de medicamentos para limitar a produção do fluido cerebroespinhal (FCE), resultando em redução da pressão intracraniana (PIC). Este trabalho descreve os achados clínicos em um cão com hidrocefalia congênita não responsiva ao tratamento médico convencional com esteróides, mas que apresentou boa resposta à associação omeprazolesteróides. O omeprazol pode diminuir a produção de FCE em cerca de $26 \%$ de acordo com estudos experimentais realizados com cães saudáveis. Porém, o uso do omeprazol em ensaios clínicos com cães enfermos, como os animais hidrocefálicos, não é descrito. Os resultados deste trabalho sugerem que o omeprazol pode ser empregado em associação ao corticóide para melhorar o estado neurológico em cães com aumento da PIC devido à hidrocefalia.

Palavras-chave: Omeprazol, fluido cerebroespinhal, hidrocefalia

1 Prof. de Semiologia e Patologia Clínica Veterinária, Clínica Médica e Terapêutica de Pequenos Animais, e Prática Hospitalar em Clínica Médica de Pequenos Animais, Faculdade de Medicina Veterinária, Universidade de Cuiabá, UNIC, Cuiabá, MT. Responsável pelo serviço técnico especializado em Neurologia Animal do Hospital Escola Veterinário da UNIC. E-mail: amamude@hotmail.com

2 Prof ${ }^{a}$ de Diagnóstico por Imagem, Faculdade de Medicina Veterinária, UNIC, Cuiabá, MT. E-mail: rosana.zanatta@gmail.com

3 Prof ${ }^{a}$ de Diagnóstico por Imagem e Clínica Médica de Pequenos Animais, Faculdade de Medicina Veterinária, UNIC, Cuiabá, MT. E-mail: raquel_ufpr@yahoo.com.br

4 Discente de mestrado do Programa de Pós-Graduação em Biociência Animal, Faculdade de Medicina Veterinária, UNIC, Cuiabá, MT. E-mail: lidi_pelegrini@hotmail.com

5 Medica(s) Veterinária(s) Residente(s) do Programa de Residência em Clínica Médica de Pequenos Animais do Hospital Escola Veterinário, UNIC, Cuiabá, MT. E-mail: katiuzi_alba@hotmail.com; fernandaviccini@hotmail.com

6 Prof. Associado, bolsista de produtividade em pesquisa 1A, Dept ${ }^{\circ}$ de Medicina Veterinária Preventiva, Universidade Estadual de Londrina, UEL, Londrina, PR. E-mail: alfieri@uel.br

Author for correspondence 
Hydrocephalus is a condition involving an increase in the volume of the cerebrospinalfluid(CSF) with abnormal dilatation of the ventricular system within the cranium, and consecutive destruction and atrophy of surrounding nervous tissue of the brain. The choice of treatment is generally dictated by the physical status, the age of the animal, and the cause of the hydrocephalus (THOMAS, 2010). Ventricle-peritoneal shunts are commonly used to divert the flow of CSF from the ventricles of the brain to the peritoneal cavity in human patients with hydrocephalus, and have proved to be an effective surgical treatment for hydrocephalus in dogs and cats (KIM et al., 2006; KITAGAWA et al., 2008). Surgery does not decrease the damage to the nervous tissue secondary to the increased intracranial pressure (ICP) that have already occurred at the moment of diagnosis; in addition, surgery might be indicated with criteria because of the risk of the anesthesia, the risk of neurological and systemic complications intraoperative, and the risk of postoperative complications of shunt placement (BAGLEY, 2004; DEWEY, 2008). Therefore, medical treatment has been commonly used to manage ICP in dogs with hydrocephalus (BAGLEY, 2004; DEWEY, 2008; THOMAS, 2010), and might include general supportive care and the administration of medications to limit the production of CSF thereby reducing the ICP. This report describes the clinical findings in a dog with congenital hydrocephalus that was unresponsive to conventional medical treatment with steroids and showed fast and intense neurological response to omeprazole administration.

A 2 month old miniature Pinscher female pup was presented to the Veterinary Teaching Hospital with a one month progressive history suggestive of cerebral dysfunction. According to the owner the pup was circling to the left, with inappropriate consciousness content (behavioral change such as aggressiveness), unable to recognize the owner and excessive vocalization. Canine distemper virus (CDV) antigen was not detected by rapid immunochromatographic test (Antigen Rapid CDV Ag Test Kit; Animal Genetics Inc. 476-1, Pajang-dong, Jangan-ku, Suwon-si, Kyonggi-do, Korea 440) and hematological and biochemical examination was within normal limits. Trauma was not suggested by the anamnesis and the physical exam not showed any systemic abnormality. Domeshaped calvarium (Fig 1A) and open fontanelles was observed at clinical exam. At the neurological evaluation a series of abnormalities were detected. The level of consciousness was alert but the content was inappropriate, the animal was not totally responsive to the environment, and did not tolerate touch and handling during the exam. Behavioral changes varied for excessive fear to aggressiveness. The dog was with compulsive walking and circling to the left (open and tight circles), mainly after excitation. The postural reactions were decreased with normal to increased spinal reflex. Cranial nerves deficits were characterized by bilateral absence of menace response (with normal photomotor reflex) and bilateral lateral strabismus. The neurological examination suggested bilateral cortical dysfunction with impairment of the third cranial nerve.

The radiographic examination of the head revealed an enlarged skull with a dome-shaped calvarium, thin bone, open fontanelles, and occipital dysplasia (Figure 1B - 1C). The ultrasonography of the brain through open fontanelles revealed severe symmetrical enlargement of the lateral ventricles with intense atrophy of the cerebral cortex (Figure 1D). The clinical history as well as the physical, neurological, and imaging findings suggested a presumptive diagnosis of congenital hydrocephalus.

The animal was initially treated with steroids - prednisolone (Predsim; Mantecorp; at a dose of $0.5 \mathrm{mg} / \mathrm{kg}$ PO BID) and had mild clinical response within the first week of therapy, but thereafter the clinical manifestations reappeared and progressed. After a period of one month the animal was returned to the Veterinary Teaching Hospital where revaluation demonstrated decreased neurological status relative to the first examination, and at this 
time the dose of steroid was increased $(1.0 \mathrm{mg} / \mathrm{kg}$ of prednisolone PO BID) in an attempt to ameliorate the neurological signs. Two weeks thereafter, the animal returned to the Hospital with poor and deteriorated neurological status totally unresponsive to the environment (constant circling, stumbling into objects, alternated level of consciousness, absence of postural reactions, and several behavioral changes
- aggressiveness). As the animal was unable to feed itself and the owner was unable to feed the dog efficiently because it was extremely aggressive, not tolerating touch and handling, the patient was hospitalized for supportive care. At this time treatment with omeprazole (Omeprazol; Generico; $10 \mathrm{mg} / \mathrm{kg}$ PO SID) was added to the conventional therapy with steroids.

Figure 1. Photographs of the patient, and respective radiographic and ultrasonographic examination of the head. (A) Dome-shaped calvarium. (B) Radiographic examination of the head with an enlarged skull (enlargement of the calvariun) with thin bone and open fontanelles. (C) Radiographic examination of the head with occipital dysplasia. (D) Ultrasonography of the brain through open fontanelles with severe symmetrical enlargement of the lateral ventricles and atrophy of the cerebral cortex.
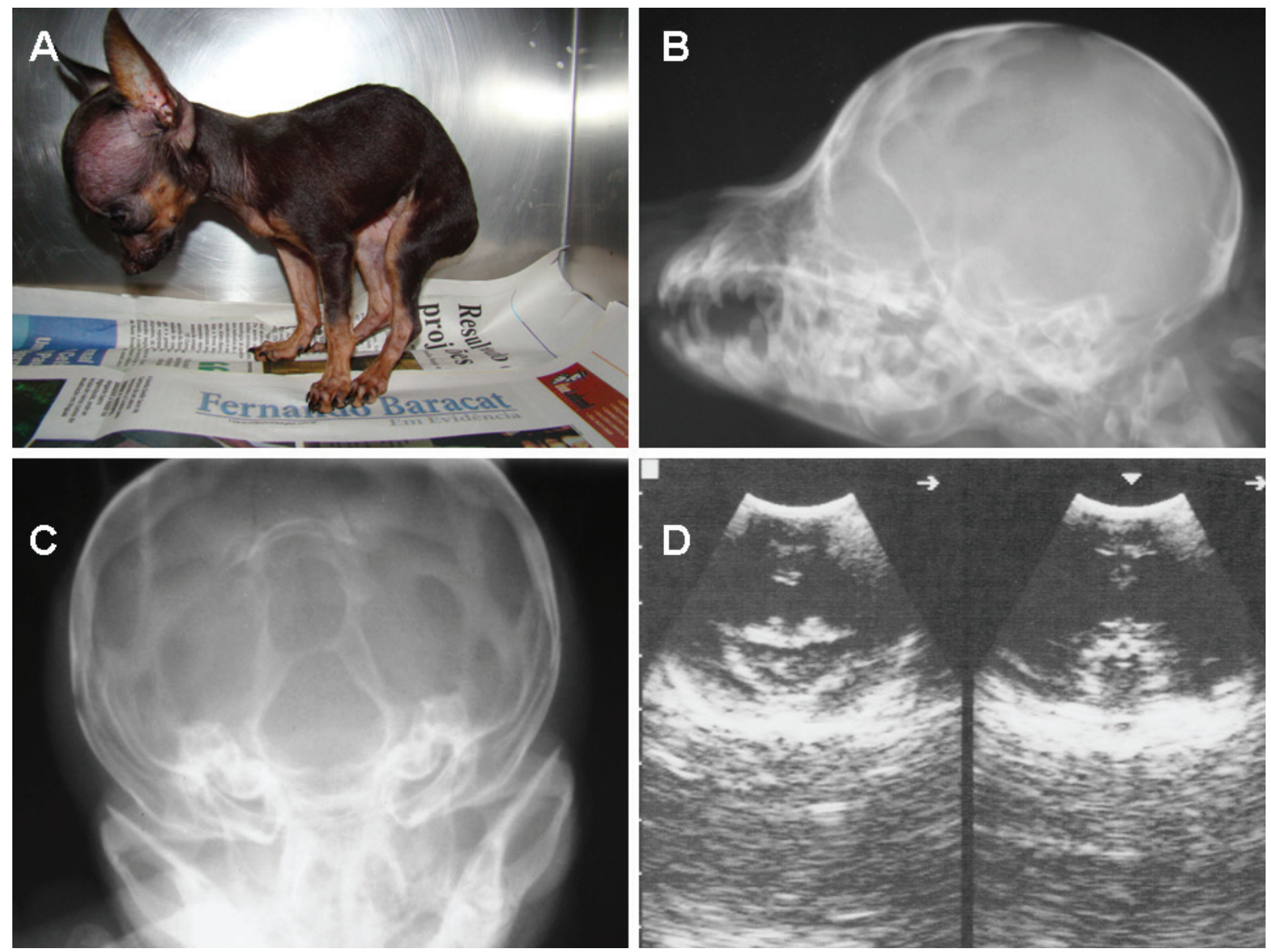

Source: Elaboration of the authors. 
Two days after the onset of omeprazole therapy, a great improvement in the general status of the dog was observed; she started to feed herself, the aggressive behavior was decreased resulting in the dog be recipient to touch and handling; the content and level of the consciousness improved, and the animal began to respond better to the environment and started to play with a stuffed toy that was made available to enrich the animal's environment. Further, the postural reaction that was absent returned to normal and lateral strabismus disappeared, although the menace deficits have persisted. One month after omeprazole therapy the dog was stable and the drugs were administered on alternate days. The animal was followed up for six month, and during this time she was stable and had demonstrated good quality of life without apparent side effect.

The importance of this report is the therapeutic use of omeprazole to decrease ICP and ameliorate neurological signs in a naturally affected dog with congenital hydrocephalus. Experimentally, omeprazole was already proved to reduce ICP by decreasing the production of CSF in healthy rabbits (LINDVALL-AXELSSON et al., 1992) and dogs (JAVAHERI et al., 1997). To the best knowledge of the authors there are no reports available within the scientific medical databases (http://www.ncbi.nlm. nih.gov/pubmed/, http://scholar.google.com.br/, and http://www.scielo.org/php/index.php) relative to the usage of omeprazole in clinical trials with naturally affected dogs with hydrocephalus. Clinical data on their use and effectiveness currently are lacking, although the use of omeprazole for the treatment of hydrocephalus and syringomyelia in dogs was already suggested within the veterinary literature (RUSBRIDGE; GREITZ; ISKANDAR, 2006; LAVELY, 2006; DEWEY, 2008; THOMAS, 2010),

Medical treatment of hydrocephalus includes general supportive care and the administration of medications to restrict the production of CSF and hence reduce the ICP. Different medications has been traditionally used with this propose such as steroids (glucocorticoids), furosemid, manitol, and carbonic anhydrase blockers (acetazolamide) (SAHAR; TSIPSTEIN, 1978; POLLAY et al., 1983; BAGLEY, 2004; DEWEY, 2008; KIM et al., 2009; PARK et al., 2009). Many of these drugs (furosemid, manitol, and carbonic anhydrase blockers) have diuretic activity, and caution must be exerted when using diuretic because electrolyte depletion is a common sequela; in addition, electrolyte loss is accelerated when diuretics are used in combination with steroids (glucocorticoids) (THOMAS, 2010). Because of all these considerations omeprazole (10 $\mathrm{mg} / \mathrm{kg}$ PO SID) (LINDVALL-AXELSSON et al., 1992; DEWEY 2008) was added to the therapy with the steroid (prednisolone) during this case.

Omeprazole, a specific inhibitor of $\mathrm{H}^{(+)}-\mathrm{K}^{(+)}$activated ATPase (proton-pump inhibitor), has a dose-dependent inhibition of CSF production as determined by cerebroventriculocisternal perfusions in the rabbit; the reduction was $25 \%$ after an intravenous dose of $0.2 \mathrm{mg} / \mathrm{kg}$ of omeprazole (LINDVALL-AXELSSON et al., 1992). Initially the effect of omeprazol was thought to be due to the $\mathrm{K}^{(+)}-\mathrm{H}^{(+)}$-ATPase activity; however the effect is independent of the $\mathrm{K}^{(+)}-\mathrm{H}^{(+)}$-ATPase activity, since Sch 28080 [a potent inhibitor of $\mathrm{H}^{(+)}-\mathrm{K}^{(+)}$-ATPase] which is more potent than omeprazole did not significantly affect CSF production (JAVAHERI et al., 1997).

Omeprazole may decrease CSF production by about $26 \%$ in experimental studies in canine model with healthy dogs without increased ICP(JAVAHERI et al., 1997). The results of this report might suggest that in naturally affected dogs with increased ICP, such as hydrocephalic dogs, omeprazole can be used to decrease CSF production in order to alleviate the increased ICP and ameliorate the neurological status. Prospective studies in naturally affected dogs have been carried out by the authors of this paper in order to clarify the therapeutic use of omeprazole in diseases that naturally course with increased ICP such as hydrocephalus. 


\section{Acknowledgements}

To the Brazilian Institute CNPq, CAPES, FAPEMAT and UNIC for financial support. The authors also wish to thank Dr. Selwyn A. Headley, Department of Basic Veterinary Sciences, School of Veterinary Medicine, St. Matthew's University, for critical revising of the manuscript, and the Veterinarian team of the Veterinary Teaching Hospital for the collaboration.

\section{References}

BAGLEY, R. S. Coma, stupor and behavioral change. In: PLATT, S. R.; OLBY, N. J. BSAVA Manual of canine and feline neurology. $3^{\text {rd }}$. ed. Gloucester, UK: British Small Animal Veterinary Association, 2004. p. 120-123. Chapter 8.

DEWEY, C. W. Encephalopathies: disorders of the brain. In:__. A pratical guide to canine and feline neurology. $2^{\text {nd }}$ ed. Ames, Iowa: Wiley-Blackwell, 2008. p. 126-129. Chapter 5.

JAVAHERI, S.; CORBETT, W. S.; SIMBARTL, L. A.; MEHTA, S.; KHOSLA, A. Different effects of omeprazole and Sch 28080 on canine cerebrospinal fluid production. Brain Research, Philadelphia, n. 1-2, v. 754, p. 321-324, 1997.

KIM, H.; ITAMOTO, K.; WATANABE, M.; NAKAICHI, M.; TAURA, Y. Application of ventriculoperitoneal shunt as a treatment for hydrocephalus in a dog with syringomyelia and Chiari I malformation. Journal of Veterinary Science, Seoul, v. 7, n. 2, p. 203-206, 2006.

KIM, J. H.; JEON, H. W.; WOO, E. J.; PARK, H. M. Dilation of the olfactory bulb cavity concurrent with hydrocephalus in four small breed dogs. Journal of Veterinary Science, Seoul, v. 10, n. 2, p. 173-175, 2009.
KITAGAWA, M.; UENO, H.; WATANABE, S.; IGARASHI, O.; UZUKA, Y.; KANAYAMA, K.; SAKAI, T. Clinical improvement in two dogs with hydrocephalus and syringohydromyelia after ventriculoperitoneal shunting. Australian Veterinary Journal, St Leonards, New South Wales, v. 86, n. 1-2, p. 36-42, 2008.

LAVELY J. A. Pediatric neurology of the dog and cat. Veterinary Clinics of North America: Small Animall Practice, v. 36, n. 3, p. 475-501, 2006.

LINDVALL-AXELSSON, M.; NILSSON, C.; OWMAN, C.; WINBLADH, B. Inhibition of cerebrospinal fluid formation by omeprazole. Experimental Neurology, Baltimore, v. 115, n. 3, p. 394-399, 1992.

PARK, C.; KANG, B. T.; YOO, J. H.; PARK, H. M. Syringomyelia in three small breed dogs secondary to Chiari-like malformation: clinical and diagnostic findings. Journal of Veterinary Science, Seoul, v. 10, n. 4, p. 365-367, 2009.

POLLAY, M.; FULLENWIDER, C.; ROBERTS, P. A.; STEVENS, F. A. Effect of mannitol and furosemide on blood-brain osmotic gradient and intracranial pressure. Journal of Neurosurgery, v. 59, n. 6, p. 945-950, 1983.

RUSBRIDGE, C.; GREITZ, D.; ISKANDAR, B. J. Syringomyelia: current concepts in pathogenesis, diagnosis, and treatment. Journal of Veterinary Internal Medicine, Wadsworth Boulevard, Lakewood, v. 20, n. 3, p. 469-479, 2006.

SAHAR, A.; TSIPSTEIN, E. Effects of mannitol and furosemide on the rate of formation of cerebrospinal fluid. Experimental Neurology, Baltimore, v. 60, n. 3, p. 584-591, 1978.

THOMAS, W. B. Hydrocephalus in dogs and cats. The Veterinary Clinics of North America. Small Animal Practice, v. 40, n. 1, p. 143-159, 2010. 
